\title{
Considering Barriers to investment in South Africa
}

\author{
K B Afful and C C Okeahalam
}

Benefit Advisory Research, Johannesburg

\begin{abstract}
This paper examines the effect of South Africa's economic fundamentals on net direct investment and net portfolio investment. The results suggest that the main determinants of investment in South Africa are resource prices, input productivity and the economic performance of the domestic economy. The results illustrate that net direct investment and net portfolio investment are close but not perfect substitutes. In addition, we find that an increase in labour input costs reduces both net direct investment and net portfolio investment. Further, an increase in fixed capital productivity increases net direct investment. Further, also the results illustrate that subsidies increase both net direct investment and net portfolio investment. Moreover, an increase in exports increases both net direct investment and net portfolio investment. Policy recommendations are thus proposed that may increase foreign direct investment in South Africa.
\end{abstract}

JEL G14, G15, 016

\section{1}

\section{Introduction}

Foreign direct investment (FDI) makes an enormous economic contribution to the economic growth of an economy. It is also a key condition for certain development objectives particularly job creation and poverty alleviation. ${ }^{1}$ Governments therefore focus on establishing policy and institutional frame-works that encourage private sector investment, focusing on FDI. This has been and is also the case in South Africa (SA), where low domestic savings are widely considered to be a fundamental constraint to growth such that other sources of capital are sought to provide for the economy's expansion needs. Accordingly, after a period of economic stagnation and disinvestment during apartheid, the democratically elected government of SA instituted policy frameworks and measures to promote a more stable and outward-oriented economy such as tariff liberalisation, a relatively austere fiscal policy, infrastructural investment and stabilising inflation. ${ }^{2}$ These were intended to foster an investment climate to attract FDI into SA.
Although SA is responsible for a major source of FDI flows to other Southern African Development Community (SADC) countries, it has received relatively little FDI in turn from the SADC countries it has invested in. In the SADC region, $\mathrm{SA}$ is the recipient of the highest inflows of FDI from non-SADC countries. However, it receives relatively low FDI as compared to other emerging economies. This has increased the concern of both policymakers and market practitioners in SA (Jenkins \& Thomas, 2002). The dearth of FDI in SA is also held to be partly accountable for its high domestic unemployment rates. SA's relatively low levels of FDI have stimulated increased discussions between government, market practitioners and policymakers about how to encourage FDI flows into SA (National Treasury, 2003). Furthermore, in lieu of the fact that SA won the bid to host the World Cup in 2010, there is a greater need to increase its domestic infrastructural and real investment.

The debate about how to encourage FDI and real investment in SA is the raison d'etre for writing this paper. The hypothesis underlying this paper is that the economic fundamentals 
and regulatory framework of the SA economy are responsible for its low FDI flows. The paper provides an overview of FDI trends in SA. It also examines the factors that impede FDI flows in SA and uses panel data to analyse the barriers to investment in SA. The paper recommends a practical framework to overcome the challenges identified. The structure of the paper is as follows: the ensuing section, Section 2, provides a background and overview of investment and FDI in SA. This is followed by Section 3, which is a literature review of the salient findings of past research on the factors that hinder investment from both domestic and foreign sources. Section 4 presents the results of the empirical analysis of the factors that impede investment in SA. In the last section, we conclude and provide a summary of the relevant findings as well as policy recommendations to enhance FDI in SA.

2

\section{Background and overview of FDI in South Africa}

This section of the paper discusses the main trends of FDI flows in SA.

Table 1 shows the average percentage share of gross foreign direct investment - GFDI denotes: gross foreign direct investment in sectors whose GFDI growth rate exceeds 4 per cent (out of 46 different economic sectors). It illustrates that the four sectors with the highest GFDI per centage share are general government services, business services, transport and storage services and finance and insurance services. While this may illustrate an investment bias in the destination of GFDI between the different economic sectors, it is important to note that growth of the SA economy requires a strategic focus of GFDI in certain core sectors that will significantly increase the country's economic growth.
Table 1

Sectoral share of gross foreign direct investment from 1970-2000 (average percentage share of total FDI at 1995 constant prices)

\begin{tabular}{|l|c|}
\hline Economic sector & $\begin{array}{c}\text { Average percentage } \\
\text { share of total } \\
\text { FDI in per cent } \\
\text { (1970 - 2001) }\end{array}$ \\
\hline $\begin{array}{l}\text { General government } \\
\text { services }\end{array}$ & 13.83 \\
\hline Business services & 10.92 \\
\hline Transport and storage & 10.46 \\
\hline Finance and insurance & 10.22 \\
\hline Electricity, gas and water & 7.25 \\
\hline $\begin{array}{l}\text { Agriculture, forestry } \\
\text { and mining }\end{array}$ & 5.38 \\
\hline $\begin{array}{l}\text { Wholesale and } \\
\text { retail trade }\end{array}$ & 5.32 \\
\hline Other mining & 4.35 \\
\hline \multicolumn{1}{|c|}{ Source: South African Reserve Bank (2002) } \\
\hline
\end{tabular}

SA's average investment to GDP ratio in the same period averaged only 16 per cent. The appropriate investment to GDP ratio required for sustained economic growth is 25 per cent (Lewis, 2001). SA's gross domestic fixed investment (GDFI) as a percentage of GDP was 15 per cent in 2001. It increased by 6 per cent in the first three quarters of 2002 (National Treasury, 2002).

Furthermore, despite an increase in GDFI, the South African Reserve Bank (2002) indicated that net FDI fell in 2002 regardless of the significant reduction in FDI outflows. The disappointing FDI performance confirms a somewhat volatile FDI trend with an average FDI of R4.6 bn a year as found by Stein (2002). This excludes the years 1997 and 2001 when the partial privatisation of Telkom and the delisting of De Beers brought in over R17 bn and $\mathrm{R} 57$ bn respectively. ${ }^{3}$

As suggested by the above-mentioned facts, many of the structural challenges concerning investment promotion have survived apartheid. The following section of the paper highlights and discusses findings of past studies on the determinants of investment and FDI. 
3

\section{Literature review}

This section of the paper outlines the salient findings of past research studies on the determinants of investment and FDI. Firstly, Mason and Harrison (2002) find that investment barriers may be classified as demand and supply-side investment barriers. Demandside investment barriers encompass all factors that reduce the demand for capital for both domestic and foreign investment. Supply-side investment barriers on the other hand, include all factors that reduce the capital inflow of investment funds that investors would want to invest. Furthermore, Morisset and Neso (2002) find that administrative barriers to investment such as administrative costs and operational procedures restrict entry and cause international investment flow imbalances. Administrative delays related to obtaining land access, building permits, government regulations and state intervention in the firm's operations significantly reduce investment flows. Other related administrative constraints include the existing administrative structures, planning policies, land ownership laws and the labour laws of the country. Such policies close off the domestic economy to capital inflows, resulting in disparate rates of return between domestic and international financial markets. Consequently, Brown and Stern (2001) find that such protectionist and restrictive policies increase labour and capital costs, deter FDI and engender capital flight. Suleman and Naude (2003) further confirm the adverse effects of protectionist tariffs and quotas.

Furthermore, the absence of property rights, competition policy, infrastructure and appropriate institutions discourages FDI (Ramamurti \& Doh, 2004). Also, a lack of technological infrastructure - a demand-side investment barrier - impedes investment and limits the efficiency of the capital market as highlighted by Harms (2001) and Ngowi (2001). Chen and Kwan (2000) find that a large regional market, appropriate infrastructure and preferential investment policies stimulate FDI inflows positively and the domestic spatial location of FDI. Lack of appropriate capital market technological and infrastructural capacity create asymmetric information, market friction, uncertainty, asset mismatch and inefficient capital markets.

Moreover, investors are deterred by adverse country risks, a supply-side barrier to FDI. Country risk comprises of political, economic and business risks. In this regard, Schnitzer (1999) and Linz (2002) find that as the risk of expropriation increases, FDI inflows decrease. Terrorist attacks and political crisis are also major risks. Also, the growing economic linkage between countries increases the transmission of economic shocks between countries and regions. In relation to the fact the findings by Schnitzer and Linz noted previously, Heintzl (2000) finds that the investment rate in SA is affected by the degree of domestic, social and political conflict.

Dunning (1996) who has made a significant contribution to the area of research on FDI, finds that the economic fundamentals of an economy determine FDI flows significantly. Farrell, Gaston and Sturm (2004), Narula and Wakelin (1998) and Pigato (2001) similarly find that domestic macroeconomic conditions as well as the domestic business and economic climate may either deter or promote investment. Asiedu (2004) finds that large markets, domestic natural resource endowments, appropriate infrastructure and an educated labour force, a proficient legal system and a conducive investment regulatory framework stimulate FDI positively. For instance, growth in imports stimulates inward FDI in China as found by Liu, Wang and Wei (2001). Macroeconomic conditions impact on a country's exchange rate, which in turn affect FDI flows and the acquisition of international firms as highlighted by Baek and Okawa (2001) and Blonigen (1997). Nachum, Jones and Dunning (2001) find that there is a linkage between the international competitiveness of firms and their home countries.

Relatively high tax burdens may also deter FDI. Branstetter and Feenstra (2002) find that tariff structures may adversely impact on FDI flows and cause the exit of multinationals. 
Asiedu and Lien (2004) find that the adverse effects of capital controls on FDI vary by region. However, Tung and Cho (2000) find that tax incentives are effectual in stimulating FDI and attracting specific forms of FDI. Therefore, statutory regulations may have a positive or adverse effect on FDI. List and Co (2000) find that heterogeneous environmental regulations adversely impact FDI flows across states in America. Qiu and Tao (2001) find that local content requirements (LCR) affect a firm's mode of entry into a new market because the higher the LCR, the greater the likelihood of the firm using FDI as its mode of entry.

Asiedu (2002) argues that policies that have been successful in stimulating investment in other countries and regions are not as successful when applied to Africa. One of the reasons for this may be the relative factor prices between factor inputs in SA relative to other countries. Restuccia and Urrutia (2001) find that the relative price of investment between countries is negatively related to the investment rates across countries.
4

\section{Data and methodology}

In this section we discuss the salient features of the data used in the empirical analysis below. The data was obtained from the Trade and Industrial Policy Secretariat (TIPS) database. It includes data on the gross domestic product, FDI, macroeconomic indicators and resource input indicators for South Africa for the 1970-2003 period. A number of important features of the data used are discussed below. Selection of the data used in the empirical analysis below was based on a similar selection of variables used in Bevan, Estrin and Meyer (2005) and Dunning and Lundan (1997). Other suggested variables were collected but were not included in the empirical analysis due to the fact that the length of such data was not sufficient.

In the analysis below we analyse net direct investment and net portfolio investment. We hypothesise that since net portfolio investment is relatively more liquid in comparison to net direct investment, the same investment factors that impact on net direct investment will have different effects on net portfolio investment. We also hypothesise that net direct investment and net portfolio investment are close, imperfect substitutes.

\section{Figure 1}

Growth rate of GDP, net portfolio investment and net direct investment

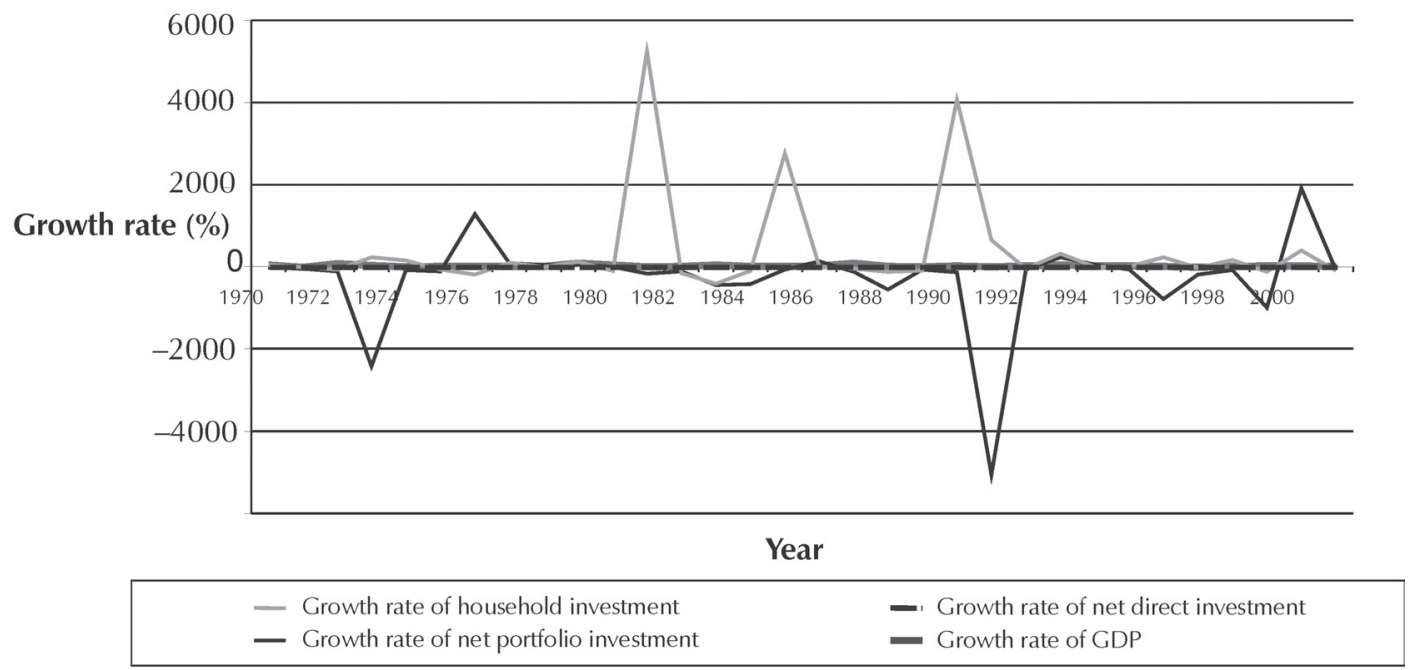


Figure 1 above illustrates that during 1970 2003 the GDP growth rate remained steady, while the growth rates of net portfolio investment and net direct investment were volatile. This may be explained by the fact that investors usually increase investments in one period and disinvest in the subsequent period. While the GDP growth rate is negative in only 7 years during the $1971-$ 2002 period, net direct investment and net portfolio investment are negative in more than ten years in the same period.

Figure 2

Ratio of net direct investment to GDP and net portfolio investment to GDP

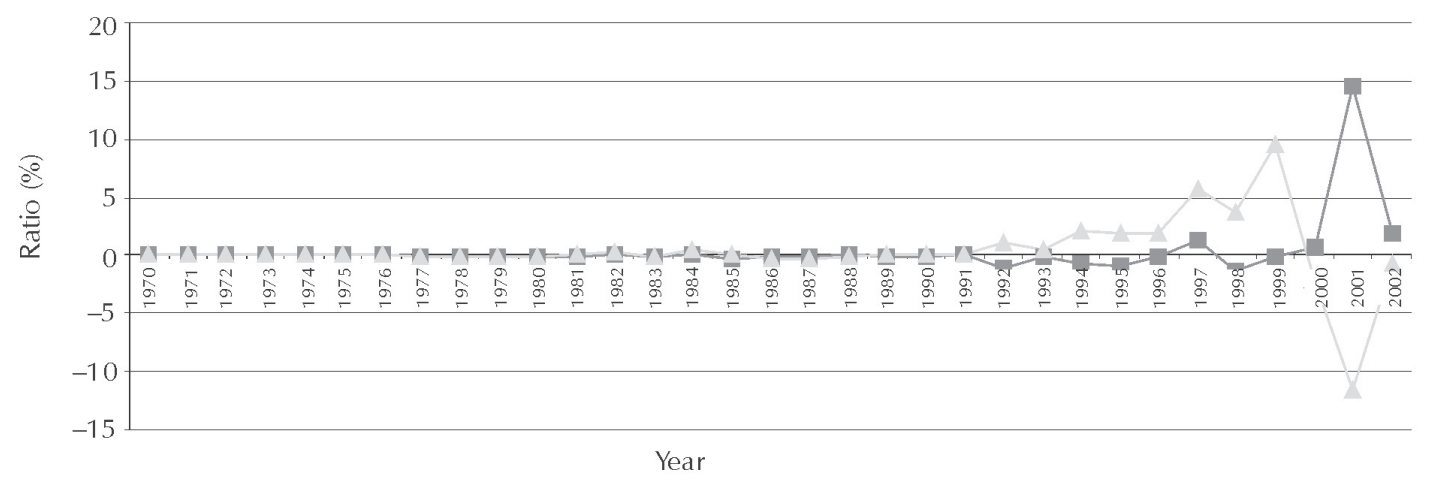

Figure 2 shows the trend of two ratios between 1970 - 2003 namely: the net direct investment to GDP ratio and the net portfolio investment to GDP ratio. It illustrates that net direct investment to GDP ratio increased at a relatively higher rate between mid-1998 and 2001 while net portfolio investment was more volatile in the same period. Figure 2 also illustrates that between 1991 - 1999 the net portfolio investment to GDP ratio grew at a relatively higher rate. The more positive growth rate of net portfolio investment and the steeper ratio of net portfolio investment to GDP suggest that portfolio investment is relatively higher than FDI in SA. This may give substance to the argument that most of the impediments to investment forestall increased FDI but increase portfolio investments because portfolio investments are more liquid.

\subsection{Methodology}

In this section we discuss the econometric methodology used in the empirical analysis conducted in this paper. We use a time-series dataset of different economic indicators for the years 1970 - 2003. We perform three timeseries tests on the dataset to ascertain the salient statistical properties of the dataset so as to ensure the robustness of the estimation. The time-series tests performed are stationarity tests, Granger-causality tests and co-integration tests. Most of the variables were differencestationary. ${ }^{4}$ Dickey-Fuller (DF) and Augmented Dickey-Fuller (ADF) tests were used in conducting the stationarity tests as well as ascertaining the order of integration of the data series. The variables used in the empirical analysis were found to be stationary and cointegrated. Also, we found that the dependent and independent variables were not simultaneously related. We use a 5 per cent significance level to interpret and infer from the regression results and only the significant regression results are discussed below.

The theoretical axiom underlying the econometric model is posited in (1) and (2) below: 


$$
\begin{aligned}
& \operatorname{NETDIR}_{\mathrm{i}}=\alpha_{0}+\alpha_{1} x_{1}+\alpha_{2} x_{2}+\ldots+\alpha_{n} x_{n}+u_{i} \\
& \operatorname{NETPORTF}_{\mathrm{k}}=\alpha_{0}^{k}+\alpha_{1}^{k} x_{1}+\alpha_{2}^{k} x_{2} \\
& +\ldots+\alpha_{n}^{k} x_{n}+u_{k} u_{j}
\end{aligned}
$$

In (1), NETDIR denotes net direct investment. $x_{1}, x_{2}$ and $x_{n}$ denote the independent variables such as GDP and interest rates while $\alpha_{1}, \alpha_{2}$ and $\alpha_{n}$ are the respective coefficients of the regression where NETDIR $_{i}$ is the dependent variable. NETPORTF $_{k}$ denotes net portfolio investment in (2). (1) and (2) illustrate that we use the same independent variables in analysing the factors that impede net direct investment and net portfolio investment.

The independent variables used in the empirical analysis may be grouped according to the following categories: input costs and productivity, tax and macroeconomic indicators. The input cost and productivity indicators consist of: consumption of fixed capital stock ratio, employment output ratio, fixed capital output ratio, fixed capital stock output ratio, fixed capital stock productivity, gross domestic fixed investment output ratio, gross domestic fixed investment, multi-factor productivity, net-markup, number of highlyskilled and remuneration per employee. The tax variables included in the empirical analysis include taxes on production, indirect taxes on goods and services and subsidies. The macroeconomic variables are namely: exports, imports of final goods and services, intermediate imports and value added at basic prices. Value added at basic prices is used in the analysis because it is a measure of the economy's productive income.

A theoretical relationship is expected between the afore mentioned variables. We now discuss the expected relationships between the preceding independent variables and the dependent variables. A priori, it is expected that an increase in the employment output ratio will reduce net direct investment because of the share of labour cost involved in using labour input rather than capital inputs. However, since net portfolio investment is a substitute of net direct investment, it is expected that an increase in the employment output ratio will increase net portfolio investment. In addition, an increase in gross domestic fixed investment output ratio, fixed capital output ratio, fixed capital stock output ratio and consumption of fixed capital stock ratio are expected to reduce net direct investment. This is because an increase in any of the preceding ratios indicates that the afore mentioned input is over-utilised in the production process. This will reduce the rate of return per unit of direct investment capital. The decrease in the rate of return on direct investment will stimulate an increase in net portfolio investment.

An increase in fixed capital stock productivity, multi-factor productivity, intermediate imports or gross domestic fixed investment is expected to increase net direct investment. This is because as the productivity of fixed capital stock and other factors increase, the rate of return per unit of investment capital increases. However, the effect of an increase in input productivity on net portfolio is expected to be ambiguous because it may increase net portfolio investment as the value of firms rise and investors increase their demand of financial assets. On the other hand, it may reduce net portfolio investment as an increase in net direct investment reduces net portfolio investment.

An increase in net-markup is expected to reduce net direct investment because it increases prices and may reduce the profit that producers may earn on sales made. The expected effect of net-markup on net portfolio investment is positive. A priori, it is expected that an increase in the number of highly-skilled will increase the efficiency of the production process. However, in the case of South Africa, there is a shortage of skilled labour and thus an increase in the number of skilled labour increases the wage bill of the average firm. Hence, a negative relationship is expected between the number of highly-skilled and net direct investment. A positive relationship, however, is expected between the number of highly-skilled and net portfolio investment as net direct investment decreases. Furthermore, an increase in the remuneration per employee is expected to reduce net direct investment and increase net portfolio investment.

A priori, it is expected that imports and direct and indirect taxes will have a negative effect on 
NETDIR $_{\mathrm{i}}$ and NETPORTF N $_{\mathrm{k}}$ Thus, an increase in the tax rate, imports, cost of labour and other factor input costs reduce national income. On the other hand, an increase in exports and value added at basic prices is expected to increase both net direct investment and net portfolio investment as national income increases. Therefore, economic variables that increase national income will increase investment, while variables that reduce national income will reduce investment.

Appendix 1 contains the regression results of the effect of SA's economic indicators on the net direct investment and net portfolio investment in Tables $1-4$. Tables 1 and 2 contain the regression results of the effect of the examined variables on net direct investment. Tables 3 and 4 present the regression results of the effect of the concerned variables on net portfolio investment The results of the regression analysis examining net direct investment is discussed prior to discussing that for net portfolio investment.

With regard to the relationship between input costs and productivity and net direct investment, an examination of Table 2 illustrates that the employment output ratio is negatively related to net direct investment. This may possibly be explained by the fact that an increase in the number of people employed increases the wage bill of the individual firm and, therefore, increases the cost of production. Furthermore, an increase in the fixed capital stock output ratio reduces net direct investment. Also, fixed capital productivity and net direct investment are positively related. In contrast with $a$ priori expectations, an increase in net-markup reduces net direct investment. This may be because an increase in net-markup increases the price of a good or service and reduces profits, thus reducing net direct investment.

Table 1 further illustrates that an increase in the number of highly-skilled employees reduced net direct investment. While it may be expected that an increase in the number of skilled labour in an economy will attract net direct investment, in South Africa skilled labour is relatively expensive because there is a shortage of skilled labour in the economy. Consequently, it may be argued that skilled employees in South Africa earn a premium above that which may be earned in an economy with relatively more skilled labour. In harmony with a priori expectations, remuneration per employee and net direct investment are negatively related. This confirms the theory that increases in resource prices increase the cost of production and reduce net direct investment.

In relation to the effect of the tax variables on net direct investment, we find that subsidies are positively related to net direct investment. This is because subsidies reduce the cost of production for the producer thus attracting net direct investment. However contrary to a priori expectations, an increase in indirect taxes increases net direct investment. It is possible that the system of indirect taxes in SA is structured such that it does not reduce the consumption of goods and services.

Concerning the macroeconomic variables, Table 1 illustrates that net direct investment and net portfolio investment are negatively related. This implies that investors have investment capital available, which they may invest in either real assets (net direct investment) or financial assets (net portfolio investment). Hence, net direct investment and net portfolio investment are substitutes. However, an increase in intermediate imports reduces net direct investment. This is due to the fact that intermediate imports mainly consist of raw materials and inputs. Therefore, an increase in intermediate import expenditure implies an increase in the retail cost of inputs and resources. The positive relationship between exports and net direct investment confirms the hypothesis that net direct investment is related to the income and economic fundamentals of the country. In contrast, an increase in imports reduces net direct investment. This is because imports are a leakage.

We now turn our attention to the analysis of the regression results for net portfolio investment. This is presented in Table 4. Table 4 indicates that with respect to the relationship between input costs and productivity and net portfolio investment, an increase in remuneration per employee reduces net portfolio investment. This may imply that although remuneration per employee directly impacts on the cost of production, it indirectly impacts negatively on net portfolio investment. 
Moreover, Table 4 illustrates that, as in the case of net direct investment, an increase in indirect taxes increases net portfolio investment. It is suspected that this relationship is indirect unlike that between indirect taxes and net direct investment. A possible explanation for this result may be that as an increase in indirect taxes increases the prices of goods and services, the revenue of the respective firms increases. This would increase the value of the shares of such firms and consequently increase net portfolio investment. Also, we find that subsidies and net portfolio investment are positively related. This further confirms the finding that subsidies reduce the cost of production. It is possible that this may also reduce the cost of investment, which increases the returns to investment. This would explain the positive relationship between subsidies and net portfolio investment.

In addition, the results confirm the prior finding that net direct investment and net portfolio investment are negatively related. Furthermore, we find that intermediate imports and net portfolio investment are negatively related. This may be explained by the possibility that an increase in intermediate imports expenditure reduces the portion of income dedicated to net portfolio investment. This is because an increase in intermediate imports expenditure increases the cost of production and the price of final goods and services. This further increases expenditure on goods and services and reduces the proportion of disposable income dedicated to net portfolio investment. Table 4 also illustrates that exports of goods and services and net portfolio investment are positively related. This confirms the theory that an increase in domestic income increases investment by both foreign and domestic investors in the domestic economy.

The foregoing results and related discussion of the empirical analysis undertaken in this paper illustrates that the economic performance of an economy is important in attracting both direct and portfolio investment. This indicates that the economic fundamentals of an economy are essential in attracting net direct investment and net portfolio investment.

\section{Conclusion and summary}

To recap, the primary objective of this paper is an analysis of the barriers to investment in SA. In this regard, we examined the effect of input costs and productivity, taxes and economic fundamentals on net direct investment and net portfolio investment.

The results obtained in this paper illustrate that an increase in labour input cost decreases both net direct investment and net portfolio investment. Thus, resource costs impact on the cost of production, which in turn signals the rate of return that may be earned from investing in SA. In addition, the results indicate that fixed capital productivity and net direct investment are positively related. This implies that one avenue through which government can increase FDI is by instituting measures to reduce the relative cost of inputs and increase the productivity of inputs. As such, factors and policies that reduce input costs, the cost of business and the cost of financial transactions in SA will encourage FDI and other forms of investment. Therefore, policymakers and the government can influence the level of FDI in SA by developing more effective incentives such as providing tax holidays and tax concessions to firms that are more labour-intensive and employ more of the previously disadvantaged population.

The paper also finds that net direct investment and net portfolio investment are negatively related and are therefore close substitutes. This is because net portfolio investment is more liquid than net direct investment. In relation to this finding, government needs to understand the trade-off between these two forms of investment so that it does not institute measures that increase net direct investment at the expense of driving away net portfolio investment.

The findings of this study expand the debate about barriers to investment in SA by highlighting the fact that SA's economic indicators and fundamentals are a signal to both foreign and domestic investors about the economic health of the SA economy. This is 
because the results illustrate that an increase in exports increases both net direct investment and net portfolio investment. Therefore, a policy to maintain sound fiscal management of the national economy is essential to promoting FDI. This is due to the fact that fiscal management impacts on the government's tax policy, which is herein found to impact on investment. Therefore SA's national economy should be prudently managed. Investors also infer the profitability of their investments in SA from the strength and economic health of the economy. Thus, the National Treasury and the SA Reserve Bank must formulate and implement strategic plans to ensure growth and effective management of the economy.

Moreover, an increase in strategically focused credit extension to the domestic private sector will increase net direct investment and household investment. To some extent, this will imply that investment projects that are politically motivated and not financially viable should be avoided. As a result, investment projects that do not provide for the core needs of the economy should be accorded lower priority. It is therefore proposed that investment capital should be focused on investment projects that reduce unemployment, foster the development of small and medium-sized enterprises (SMMEs) and increase the standard of living of employees. Implementation of the above recommendations should promote greater investment and foster FDI. Implementation of such a recommendation would go a long way towards increasing investment capital inflow.

Another dimension of the debate is whether to target foreign or local investors. In this regard, one of the reasons propounded for targeting foreign investors is that foreign investors expand the pool of available capital and resources within an economy. Dependent on the source, they may also have access to deeper and cheaper non-domestic sources of capital. In addition, they may introduce new technology, know-how, skills and innovation that could enhance productivity (Narula \& Sadowski, 2002). Furthermore foreign investors, if satisfied with their experience in an investment locality, are likely to expand production, further generate increased investments and produce multipliers for the economy.

In conclusion, this study has examined the effect of input costs and productivity, taxes and economic fundamentals on net direct investment and net portfolio investment. In future, subject to the availability of data on the regulatory structure and taxes on international trade and transactions, research on this issue could be developed. In particular this would enhance analysis on the effects of various forms of taxes on net direct investment and net portfolio investment. In addition, we hope that the results of this paper will stimulate further research on the factors that impede FDI inflows to SA. This should assist in the development of effective policies and measures to increase FDI in SA.

\section{Endnotes}

${ }^{1}$ Rather FDI should be seen as a partial solution to job creation through the multiplier effects of investment.

${ }^{2}$ Despite this policy commitment, South Africa's average investment to GDP ratio has averaged only 16 per cent between 1994 and 2000. This ratio is far below the target of 25 per cent, with FDI representing less than 1 per cent of GDP during this period. Gross domestic fixed investment (GDFI) as a percentage of GDP in 2001 was measured at 15 per cent, with private businesses and "general Government" contributing to growth, while widely restructured public corporations cut back spending during 2001. The first three quarters' GDFI of 2002 were up 6 per cent on the same period in 2001, with business, government and public corporations contributing to this growth and especially motor, agriculture, mining (platinum) and cellular telecommunications sectors as well as the development of the Coega harbour. Despite an increase in GDFI, the latest Reserve Bank Quarterly Bulletin (December 2002) indicated that net FDI fell in this period, with FDI outflows significantly reduced, following a seven-year period during which South African companies invested an average of R7 bn offshore annually. This disappointing 
FDI performance confirms a somewhat volatile trend with an average of R4.6 bn of FDI a year. This excludes the years 1997 and 2001. As suggested by this data, many of the structural challenges to investment promotion have survived apartheid. The focus of this research paper is to identify the barriers to investment experienced by the private sector and foreign investors and to propose recommendations to enable Gauteng's Department of Finance and Economic Affairs (DFEA), where appropriate, to remove obstacles to investment.

${ }^{3} \mathrm{Ibid}$. These figures need to be excluded to understand the underlying trend of FDI, especially as neither was likely to result in any great degree of the assumed benefits of FDI such as job creation.

${ }^{4}$ See Mills (1996) for greater discussion on stationarity, integration, Dickey Fuller and Augmented Dickey Fuller tests.

\section{References}

1 ASIEDU, E. (2002) "On the determinants of foreign direct investment to developing countries: Is Africa different", World Development, 30: 107-119.

2 ASIEDU, E. (2004) "Foreign direct investment in Africa: The role of government policy, institutions, and political instability", under review.

3 ASIEDU, E. \& LIEN, D. (2004) "Capital Controls and Foreign Direct Investment", World Development, 3: 479-490.

4 BAEK, I. \& OKAWA, T. (2001) "Foreign exchange rates and Japanese foreign direct investment in Asia", Journal of Economics and Business, 53: 69-84.

5 BEVAN, A.; ESTRIN, S. \& MEYER, K. (2005) "Determinants of foreign investment in transition economies", Journal of Comparative Economies, forthcoming.

6 BLONIGEN, B.D. (1997) "Firm-Specific assets and the link between exchange rates and foreign direct investment", American Economic Review, 87(3): 447-465.

7 BRANSTETTER, L.G. \& FEENSTRA, R.C. (2002) "Trade and foreign direct investment in China: A political economy approach”, Journal of International Economics, 58: 335-358.

8 BROWN, D. \& STERN, R.M. (2001) "Measurement and modelling of the economic effects of trade and investment barriers in services”, Review of International Economics, 9: 262-286.

9 BUSINESSMAP. (2000) "SADC investor survey - complex terrain”, BusinessMap, Johannesburg, South Africa.

10 BUSINESSMAP. (2001) "Regional investor survey 2001 - opportunities in waiting", BusinessMap, Johannesburg, South Africa.

11 BUSINESSMAP. (2002). "Loss in second quarter FDI disturbing”, BusinessMap, Johannesburg, South Africa.

12 CHEN, L.K. \& KWAN, Y.K. (2000) "What are the determinants of the location of foreign investment? The Chinese experience", Journal of International Economics, 51: 379-400.

13 DUNNING, J.H. (1996) "Explaining foreign direct investment in Japan: Some Theoretical Insights", in M. Yoshitomi and E. Graham (eds.), Foreign Direct Investment in Japan, London, Edward Elgar.

14 DUNNING, J.H. \& LUNDAN, S. (1997)

"Foreign direct investment in Japan and the United States: A comparative analysis", International Trade Journal, 11(2): 187-220.

15 EICHER, T. \& KANG, J.W. (2004) "Trade, foreign direct investment or acquisition: Optimal entry modes for multinationals", Working paper series, Centre for Economic Studies, University of Munich, Munich, Germany.

16 FARRELL, R.; GASTON, N. \& STURM, J. (2004) “Determinants of Japan's foreign direct investment: An industry and country panel study", 1984-1998, Journal of Japanese and International Economies, 18: 161-182.

17 HARMS, P. (2001) "International investment in a model of stochastic growth and development traps", Journal of Economics, 74: 131-155.

18 HEINTZL, J. (2000) "Distribution, investment and employment in South Africa", Paper Presented at the Trade and Industrial Policy Secretariat (TIPS) Annual Forum at Glenburn Lodge, Muldersdrift on 18-20 September, Johannesburg, South Africa.

19 JENKINS, C. \& THOMAS, L. (2002) Foreign direct investment in Southern Africa: Determinants, characteristics, and implications for economic growth and poverty alleviation, Institute of Development Studies, University of Sussex, Brighton, United Kingdom.

20 LEWIS, D. \& BLOCH, R. (1997) Spatial development initiatives: Infrastructure, agglomeration and region in industrial policy, Paper prepared for TIPS forum. 
21 LIST, J.A. \& CO, C.Y. (2000) "The effects of environmental regulations on foreign direct investment", Journal of Environmental Economics and Management, 40: 1-20.

22 LIU, X.; WANG, C. \& WEI, Y. (2001) "Causal links between foreign direct investment and trade in China”, China Economic Review, 12: 190-202.

23 MASON, C.M. \& HARRISON, R.T. (2002) "Barriers to investment in the informal venture capital sector", Entrepreneurship and Regional Development, 14: 271-287.

24 MILLS, T.C. (1996) The econometric modelling of financial time series, Cambridge University Press: Great Britain.

25 MORISSET, J. \& NESO, O.L. (2002) "Administrative barriers to foreign investment in developing countries", Working paper \# 2848, World Bank, Washington.

26 NACHUM, L.; JONES, G.G. \& DUNNING, J.H. (2001) "The international competitiveness of the UK and its multinational enterprises", Structural Change and Economic Dynamics, 12: 277-294.

27 NARULA, R. \& SADOWSKI, B. (2002) "Technology catch-up and strategic technology partnering in developing countries", International Journal of Technology Management, 23: 599-617.

28 NARULA, R. \& WAKELIN, K. (1998) "Technological competitiveness, trade and foreign direct investment", Structural Change and Dynamics, 9: 373-387.

29 NATIONAL TREASURY. (2002) Economic policy and outlook, Budget Review, National Treasury, Pretoria, South Africa.

30 NATIONAL TREASURY. (2003). 2003 Budget speech, National Treasury, Pretoria, South Africa.

31 NGOWI, H.P. (2001) "Can Africa increase its global share of foreign direct investment flows (FDI)?", West Africa Review, 2(2): 1-22.

32 PIGATO, M.A. (2001) "The foreign direct investment environment in Africa", Africa Region Working Paper Series No. 15, World Bank.

33 QIU, L.D. \& TAO, Z. (2001) "Export, foreign direct investment and local content requirement", Journal of Development Economics, 66: 101-125.

34 RAMAMURTI, R. \& DOH, J.P. (2004)

"Rethinking foreign infrastructure investment in developing countries", Journal of World Business, 39: 151-167.

35 RESTUCCIA, D. \& URRUTIA, C. (2001)

"Relative prices and investment rates", Journal of Monetary Economics, 47: 93-121.

36 SAMOLYK, K. (1992) "Banking conditions and regional economic performance: Evidence of a regional credit channel", Journal of Monetary Economics, 34: 259-278.

37 SCHNITZER, M. (1999) "Expropriation and control rights: A dynamic model of foreign direct investment", International Journal of Industrial Organization, 17: 1113-1137.

38 SOUTH AFRICAN RESERVE BANK. (1998) Quarterly review, South African Reserve Bank, Pretoria, South Africa.

39 SOUTH AFRICAN RESERVE BANK. (2002) Quarterly bulletin, South African Reserve Bank, Pretoria, South Africa.

40 STEIN, G. (2002) "Mixed picture on investment from the Reserve Bank", BusinessMap

Foundation Update, BusinessMap, Johannesburg, South Africa.

41 SUlEMAN, A. \& NAUDE, W.A. (2003) "The competitiveness of South African manufacturing: A spatial view", Studies in Economics and Econometrics, 27: 29-52.

42 TRADE AND INDUSTRIAL POLICY STRATEGY DATABASE (TIPS Database) (2004) Trade and industrial policy strategy secretariat, Johannesburg, South Africa.

43 TUNG, S. \& CHO, S. (2000) "The Impact of tax incentives on foreign direct investment in China", Journal of International Accounting, Auditing and Taxation, 9(2): 105-135.

44 VAN DE LAAR, M. (2000) Foreign direct investment decisions under uncertainty in central and Eastern Europe, Working Paper, Business Investment Research Centre, University of Maastricht, Netherlands.

45 VENKATARAMANY, S. (2003) Determinants of foreign direct investment in India: An empirical analysis of source countries and target industries, Paper presented at the Seventh International Conference on Global Business and Economic Development. 


\section{Appendix 1 \\ Regression results}

Table 1

Regression results of net direct investment

\begin{tabular}{|l|c|c|c|}
\hline \multicolumn{1}{|c|}{ Regression indicator } & Value & Regression indicator & Value \\
\hline R-Squared & 99.645 & R-Bar-Squared & 98.344 \\
\hline Standard error of regression & 2097.9 & F-stat. F( 22, 6) & 76.5925 \\
\hline Mean of dependent variable & 2523.6 & P-value of F-stat & 0.00 \\
\hline Residual sum of squares & 2.64 & Standard deviation of Dependent Variable & 15277.5 \\
\hline Akaike Information Criterion & -263.1156 & Equation Log-likelihood & -240.1156 \\
\hline D-W Statistic & 3.0886 & Schwarz Bayesian Criterion & -280.3254 \\
\hline
\end{tabular}

Source: Own computation from TIPS Database

Table 2

Regression results of net direct investment continued

\begin{tabular}{|c|c|c|c|}
\hline Variable & Coefficient & Standard error & P-value \\
\hline Constant & -642063.9 & 352194.2 & .090 \\
\hline Portfolio investment & -.56066 & .056971 & .000 \\
\hline Employment output ratio & -128021.7 & 44329.8 & .012 \\
\hline Remuneration per employee & -19.0982 & 5.5788 & .004 \\
\hline Net markup & -19812.3 & 7027.8 & .014 \\
\hline Gross domestic fixed investment output ratio & 668255.2 & 785327.2 & .409 \\
\hline Fixed capital stock ratio & 1004162 & 414913.7 & .030 \\
\hline Consumption of fixed capital stock ratio & -1481180 & 1460641 & .328 \\
\hline Fixed capital stock productivity & 14187.8 & 4788.2 & .010 \\
\hline Multi-factor productivity & 175.6337 & 2446.9 & .944 \\
\hline Intermediate imports & -1.4158 & .43969 & .006 \\
\hline Gross domestic fixed investment & -.80400 & .67308 & .252 \\
\hline Number of highly-skilled & -.10078 & .043727 & .037 \\
\hline Value added at basic prices & .18505 & .16355 & .277 \\
\hline Taxes on production & 1.2201 & 1.1368 & .301 \\
\hline Subsidies & 4.5073 & 1.4645 & .008 \\
\hline Indirect taxes on goods and services & 1.9435 & .19924 & .000 \\
\hline Exports of goods and services & .71530 & .10964 & .000 \\
\hline Imports of goods and services & -.68620 & .26062 & .020 \\
\hline
\end{tabular}




\section{Table 3}

Regression results of net portfolio investments

The dependent variable is net portfolio investment. 33 observations were used for the estimation from $1970-2002$.

\begin{tabular}{|l|c|l|c|}
\hline \multicolumn{1}{|c|}{ Regression indicator } & \multicolumn{1}{c|}{ Value } & \multicolumn{1}{c|}{ Regression indicator } & Value \\
\hline R-Squared & 99.126 & R-Bar-Squared & 95.921 \\
\hline Standard error of regression & 3639.8 & F-stat. F( 22, 6) & 30.9288 \\
\hline Mean of dependent variable & 1608.3 & P-value of F-stat & 0.00 \\
\hline Residual sum of squares & $7.95 \mathrm{E}+07$ & Standard deviation of Dependent Variable & 16866.3 \\
\hline Akaike Information Criterion & -279.0949 & Equation Log-likelihood & -256.0949 \\
\hline D-W Statistic & 3.0850 & Schwarz Bayesian Criterion & -296.3047 \\
\hline
\end{tabular}

Source: Own computation from TIPS Database

\section{Table 4}

Regression results of net portfolio investment

\begin{tabular}{|c|c|c|c|}
\hline Variable & Coefficient & Standard error & P-value \\
\hline Constant & -988928.1 & 730597.9 & 0.197 \\
\hline Net direct investment & -1.7095 & 0.19967 & 0.000 \\
\hline Employment output ratio & -208005.9 & 101415.2 & 0.059 \\
\hline Remuneration per employee & -30.5991 & 13.8384 & 0.044 \\
\hline Net markup & -31362.3 & 16366.0 & 0.076 \\
\hline Gross domestic fixed investment output ratio & 1052634 & 1328386 & 0.441 \\
\hline Fixed capital stock ratio & 1599034 & 905006.6 & 0.099 \\
\hline Consumption of fixed capital stock ratio & -2072633 & 2700331 & 0.456 \\
\hline Fixed capital stock productivity & 23059.1 & 11021.9 & 0.055 \\
\hline Multi-factor productivity & -447.8257 & 4230.8 & 0.917 \\
\hline Intermediate imports & -2.3029 & 1.0438 & 0.045 \\
\hline Gross domestic fixed investment & -1.2704 & 1.2044 & 0.309 \\
\hline Number of highly-skilled & -0.15594 & 0.098080 & 0.134 \\
\hline Value added at basic prices & 0.27293 & 0.29188 & 0.366 \\
\hline Taxes on production & 1.9466 & 2.0888 & 0.367 \\
\hline Subsidies & 7.6639 & 3.0234 & 0.024 \\
\hline Indirect taxes on goods and services & 3.3246 & 0.63377 & 0.000 \\
\hline Exports of goods and services & 1.1941 & 0.29829 & 0.001 \\
\hline Imports of goods and services & -1.0992 & 0.59233 & 0.085 \\
\hline
\end{tabular}

